\title{
Mindfulness and Sustainability: Utilizing the Tourism Context
}

\author{
Attila Lengyel ${ }^{1}$ \\ ${ }^{1}$ College of Szolnok, Hungary \\ Correspondence: Attila Lengyel, 5000 Szolnok Tiszaligeti Sétány 14 Hungary, Hungary. E-mail: \\ latila@t-online.hu
}

Received: August 10, 2015 Accepted: September 25, 2015 Online Published: October 22, 2015

doi:10.5539/jsd.v8n9p35 URL: http://dx.doi.org/10.5539/jsd.v8n9p35

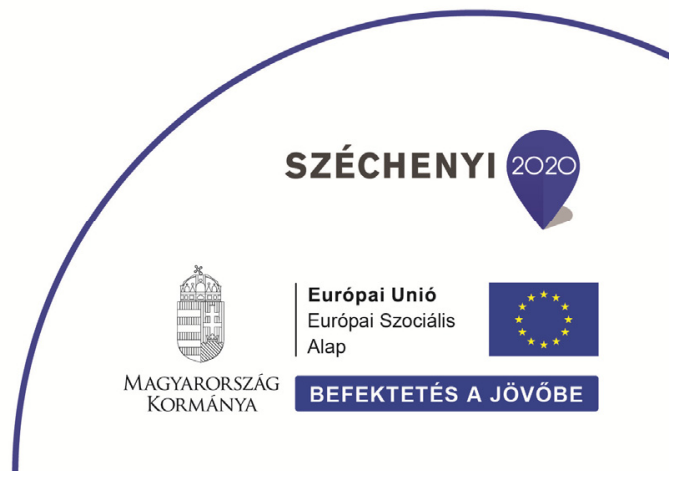

The publishing fee of the article was financed by: TÁMOP-4.2.2.B-15/1/KONV-2015-0015

Tehetséggondozási kutatómühelyek fejlesztése a Szolnoki Föiskolán

\begin{abstract}
After several decades of sustainability efforts humanity is still on track to worst-case climate scenario. Other planetary boundaries have also been transgressed. The symptoms point to a root cause termed by many as a crisis of perception and value system. Our consumption-oriented world view is unsustainable. What can catalyze a perceptual paradigm shift needed to avoid global socio-ecological collapse in the long-run? Besides its manifold beneficial effects tested clinically, mindfulness has been found to be positively correlated with sustainable behavior. The article gives a theoretical grounding of mindfulness highlighting some new aspects and argues that the tourism context serves as an exceptionally suitable medium for learning mindfulness techniques. Expanding on earlier openness to new experience and Google Trends research of the author it is demonstrated that tourists have a markedly raised level of openness to new experience and also that there is a strong demand side business case for developing more mindfulness-based tourism products both globally and specifically for Hungary. The study provides further evidence of the short fade-out period of positive vacation effects and shows what type of destinations and accommodations potential wellness and ecotourists consider best for learning mindfulness.
\end{abstract}

Keywords: mindfulness, sustainability, tourism, paradigm shift, Google Trends

\section{Introduction}

\subsection{The Ineffectiveness of Sustainability Efforts and Possible Reasons}

On the 289 pages of Hungary's most comprehensive development plan, the National Development 2030 (Mirror translation of the original: Nemzeti Fejlesztés 2030), the Hungarian counterparts of the words „sustainable”, „unsustainable”, „sustainability” or their agglutinated forms occur 247 times. Since the publication of Rachel Carson's Silent spring in 1962 countless conferences, scientific publications, organizations have been dealing with issues of sustainability locally, regionally and globally. In spite of the seemingly growing awareness of sustainability challenges humanity is still on track to worst case (RCP8.5) climate change scenario as highlighted by Global Carbon Budget 2014 report (Le Quéré et al., 2014). Other planetary boundaries such as biosphere integrity, biogeochemical flows, and land-system change have also been transgressed (Steffen et al., 2015). 
There are several other problem areas whose analysis is beyond the scope of this article (e.g. inequality gap) Based on NOA ESRL data Figure 1. shows co2 emission figures since 1992 and also the venues of the COP climate conferences in the same period.

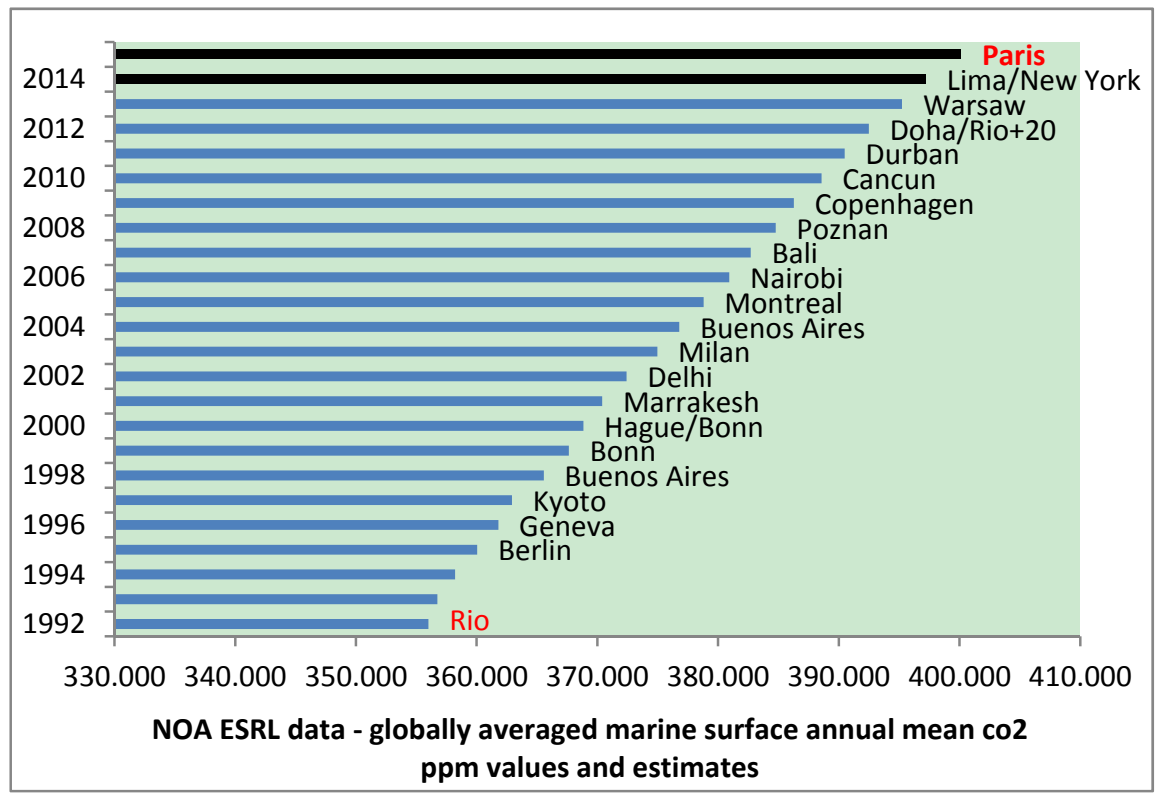

Figure 1. COP conferences and corresponding global co2 ppm figures

It might seem astonishing why in the face of the well-known signs and serious warnings from the scientific community humanity still chooses to postpone urgent and inevitable decisions. Present mental models and perception of climate change is one possible factor (Sterman, \& Sweeney, (2007). „Creeping normalcy” and the „false alarm effect" can also play a significant role in the hesitation to act (Diamond, 2011). Most people are not aware of the fact that hardly noticeable gradual changes (creeping normalcy) might add up to a point where the whole system suffers an abrupt change termed state/regime shift (Scheffer, Carpenter, Foley, Folke \&Walker, 2001, Carpenter et al., 2011). The „false alarm effect” originally portrayed in Aesop's fable here means that people might think if the ecosystem is still functioning in spite of the alarming voices of the recent decades, the problem cannot be that big. These two reasons seem to be supported by Google Trends data and findings from literature. There has been a steady downward trend in the global popularity of the search expressions „sustainable”, ,sustainable development” since 2005, for „global warming” since 2007, for „,sustainability” since 2010 and with the exception of a sudden high outlier in 2009 for „climate change” since 2007 . While over $80 \%$ of tourists are aware and acknowledge that tourism-related aviation contributes to global warming (Gössling, Haglund, Kallgren,Revahl, \& Hultman, 2009), people in general believe that action can be postponed (Sterman \& Sweeney, 2007). Another possible explanation of hesitation might be technological optimism. Although technological innovation is important in addressing sustainability challenges (Kriegler et al., 2014), a purely technological fix seems unlikely (Polimeny, Mayumi, Giampietro, \& Alcott, 2009). The strongest reason for hesitation and inaction, however, probably has to do with a deeper problem inherent in our modern world view. The worsening socio-ecological crises at its root is essentially a crisis of our perception of the world and our value system (Capra, 1982). It resonates with the final conclusions Diamond draws in his book (Diamond, 2011) and also with the views of several other authors pointing out that the consumption paradigm of modern societies is unsustainable (Boudrillard, 1998, Martinez-Alier, Pascual, Zaccai \& Zaccai, 2010, Urry, 2010, Zsolnai, 2011, Harvey, 2011, Randers, 2012). Since E.F.Schumacher wrote his influential book titled Small is beautiful (Schumacher, 1973), alternative economic approaches considering spiritual values a guiding principle have been gaining momentum. Still, the big questions remain before the Paris climate conference expected to be a milestone in the history of mitigation efforts. What will persuade people in rich countries to give up some of their luxury and comfort and members of developing countries not to want to pursue the „American dream”? What can catalyze a paradigm shift in our perception of the world and value system?

\subsection{Mindfulness and Its Significance}

The present study argues that mindfulness is a universal and effective instrument to catalyze such a paradigm 
shift both at the individual and collective level and the tourism context is uniquely suited for learning mindfulness skills. The word mindfulness became popular when clinical psychologists first started to test their effects and therapeutic value (Kabat-Zinn, 1982, Kabat-Zinn et al., 1985). Since the first article in 1982 the number of mindfulness research publications have been growing exponentially (Black, 2014), a trend similar to co2 emission growth depicted in Figure 1. The word "mindfulness" was first used as a translation of the Pali word "sati" originally meaning "remembrance" (Davids 1881 in Gethin, 2011) and by the early 1900s became a widely accepted term (Davids 1910 in Gethin, 2011). Using the word mindfulness instead of meditation is justifiable for at least four reasons.

1) It is a general word and represents the universal nature of the techniques it involves.

2) It is the "core" or "heart" of Buddhism (Nyanaponika, 1962, Nanamoli and Bodhi in Kabat-Zinn, 2003) and is not burdened with the religious "baggage" alien and indigestible for westerners.

3) Meditation can mean contemplating, pondering, thinking deeply about something, especially in western religious traditions. Mindfulness aims at quieting the mind completely.

4) Techniques such as TM (Transcendental Meditation) are also called meditation, however, there are crucial differences between them and mindfulness type techniques.

Clinical psychologists, neurologists, and research scientists of other disciplines have tested and examined the effects of mindfulness meditation techniques. Mindfulness was found to have significant positive effects on people with cardiovascular problems (Parswani, Sharma, \& Iyengar, 2013), high blood pressure (Hughes et al., 2013), cancer (Matchim, 2010), acute pain (Zeidan et al., 2011), depression caused by fibriomyalgia (Sephton et al., 2007), irritable bowel syndrome (Gaylord et al., 2011), attachment anxiety (Pepping, O'Donovan, \& Davis, 2014) and several other physical and psychological conditions. It improves immune function (Davidson et al., 2003) and positively alters brain structure (Hölzel et al., 2011). Mindfulness has been tested in schools on children, teachers and parents (Weijer-Bergsma, Formsma, Bruin, \& Bögels, 2012), in the workplace on employees (Reb, Narayanan, \& Ho, 2013) and on decision makers (Fiol \& O'Connor, 2003). Mindfulness has a provably positive effect on creativity (Horan 2009, Ren et al., 2011, Colzato, Ozturk, \& Hommel, 2012) which is a prerequisite of any innovative process (Amiable, 1997). Mindfulness has been found to be positively correlated with sustainable behavior (Jacob, Jovic, \& Brinkerhoff, 2008, Amel, Manning, \& Scott, 2009). Through raising awareness, and reducing the incidences of reacting habitually and acting on "auto-pilot", it can reduce exposedness to advertising, escalating consumption and material gain. (Rosenberg, 2004, Brown \& Kasser, 2005). Persuaded by the accumulating scientific evidence, in 2014 the British parliament launched an all party parliamentary group to examine how mindfulness could be used in health-care, education and criminal justice. It is becoming mainstream in the corporate world. Some of the companies utilizing mindfulness include Monsanto, Intel, Google, Adobe Systems, Goldman Sachs Group, Deutsche Bank, Apple, Procter, \& Gamble. Figure 2. shows the positive effects of mindfulness type meditation that can easily be translated into financially accountable benefits and in turn into a possibly higher level of sustainability. The effects marked in light blue are supported by peer-reviewed literature, while the last items in the effect chains are common sense assumptions. This representation is incomplete and does not show interconnectedness of the effects for the sake of an easier overview. 


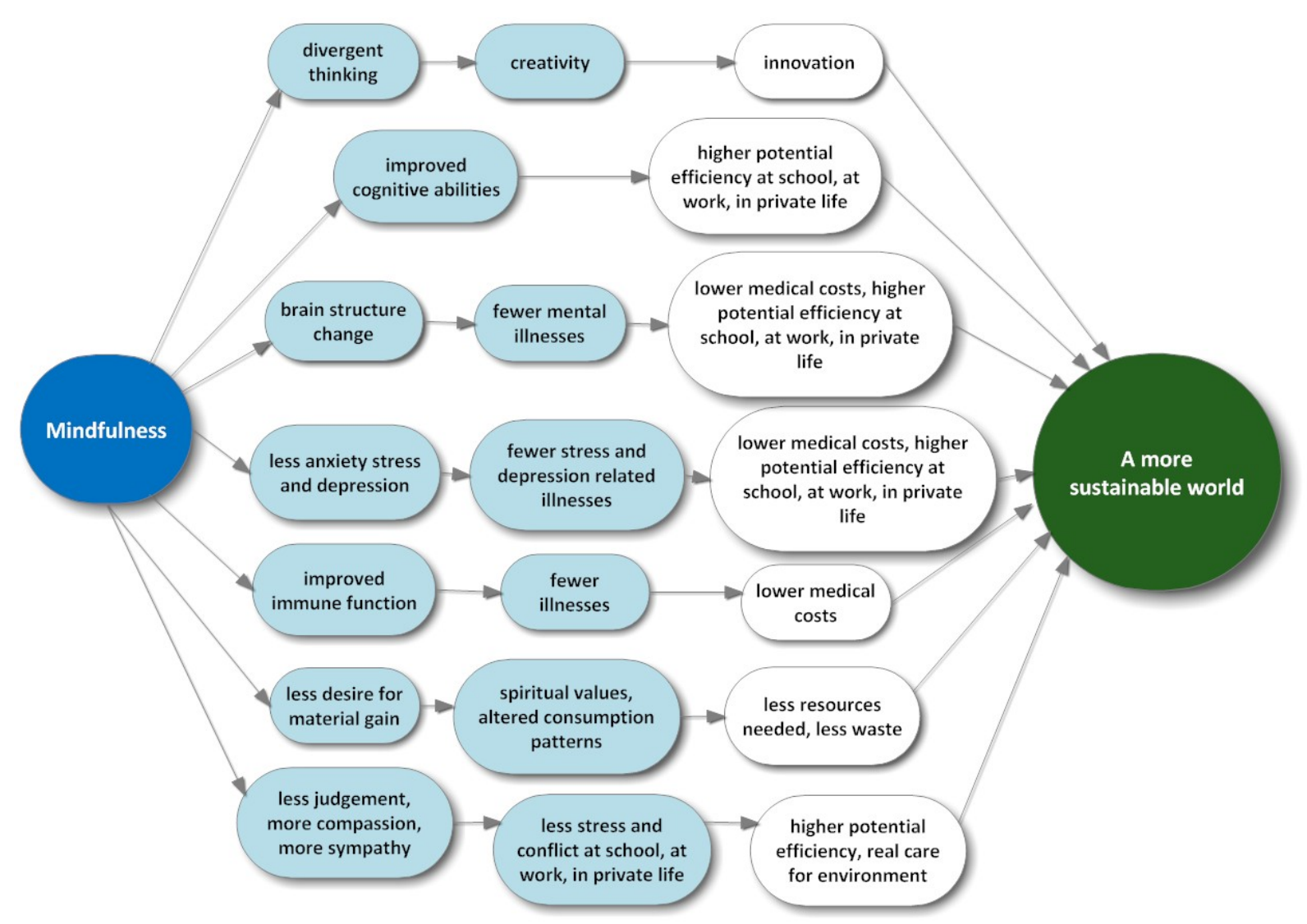

Figure 2. Benefits of mindfulness and their possible positive effects on sustainability

Many attempts have been made to define the mindfulness construct (Brown \& Ryan 2003, Baer, Smith, Hopkins, Krietemeyer, \& Toney, 2006) and its working mechanism (Holzel et al., 2011) and also to define the term itself (Kabat-Zinn, 2003, Bishop et al., 2004). Most definitions share some characteristics such as: paying attention to anything that arises outside and inside, paying attention non-judgmentally, having an attitude of acceptance, being present-centered. With few exceptions the definitions seem to miss a very important point, "witnessing" (Osho, 1988) which is basically the reinforcement of the ancient vedic principle of "neti neti" (neither this, nor that) (Hume, 1921). In Buddhism it is the principle of non-attachment (Liu, 1993, Wallace, 2005). Their practical meaning is that while being mindful one should not become identified with anything. Non-attachment is central to the BPM model of mindfulness proposed by Grabovac et al. and as pointed out by them probably the most important benefit of mindfulness from a clinical point of view as well (Grabovac, Lau, \& Willett, 2011). Witnessing and non-attachment is mentioned as the focal point of meditation by contemporary masters like Tolle or Mooji (Tolle, 2005, Mooji in Ispired times 2012). Another often neglected aspect of mindfulness is enlightenment which is the ultimate goal of insight mindfulness practices (Brown \& Engler 1980, Mikulas, 2011). The mainly psychiatric literature on mindfulness refers to mindfulness as a form of intervention and usually stops at a point of increased psychological wellbeing. 


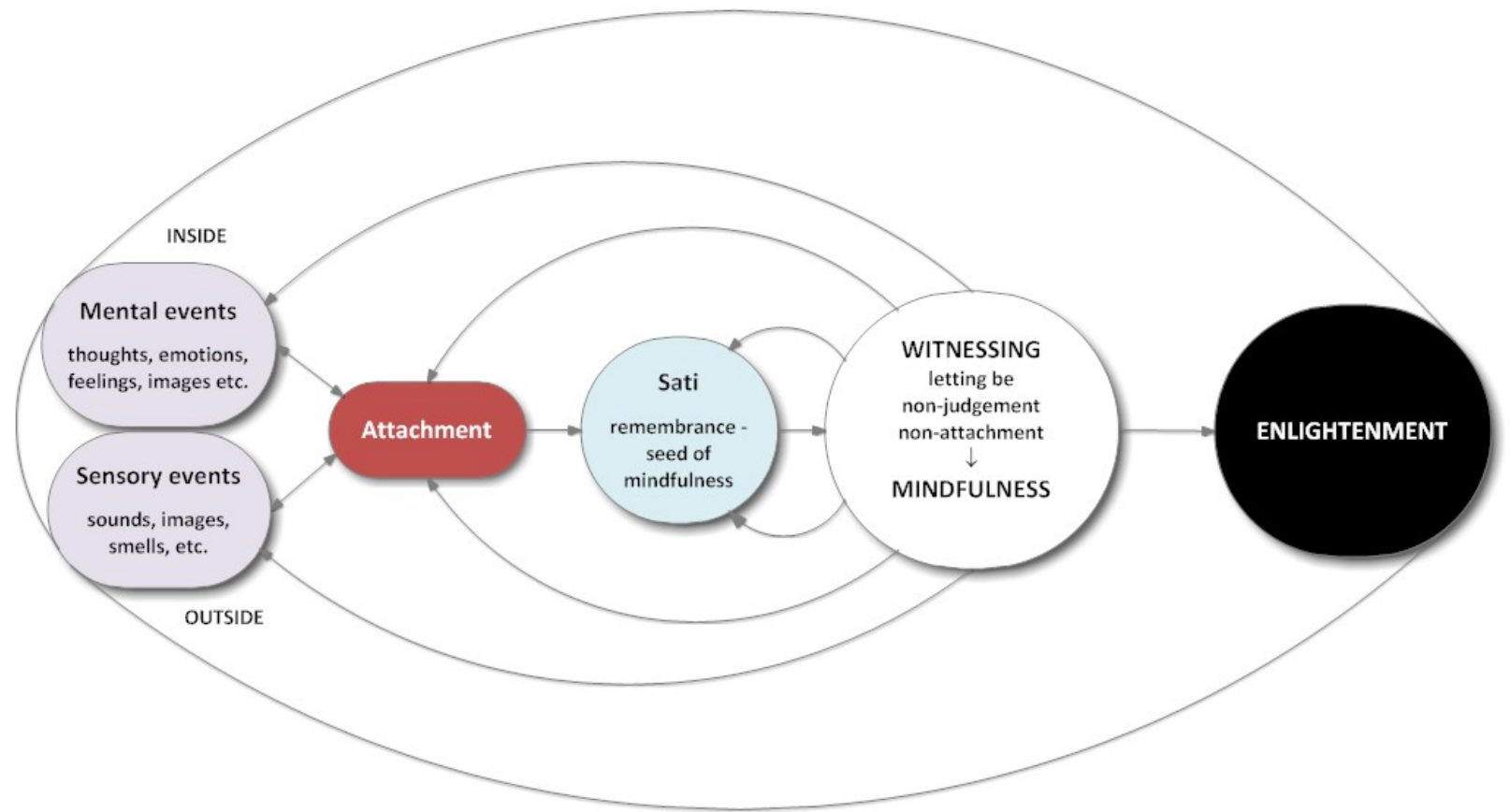

Figure 3. Mechanism and paradoxical nature of mindfulness

Figure 3. attempts to show the mechanism of mindfulness incorporating remembrance (sati), the "letting go" attitude (neti neti, non-attachment, witnessing), enlightenment as the final step and also the paradoxical nature of mindfulness. Summing up what was previously said a new definition of mindfulness could be the following: Remembering to stay witnessing in the present moment non-judgmentally, letting anything inside or outside arise and disappear with the ultimate purpose of attaining enlightenment. It should be underlined that besides the basic breathing (Anapanasati) and insight meditation technique (Vipassana) used in mindfulness, this word is an umbrella term and might include techniques such as yoga meditations, zen and taoist meditations, tai chi etc. Acquiring new skills (Herold, Davis, Fedor, \& Parsons, 2002) especially mindfulness skills requires an open attitude (Nath Hahn, 1999, Osho, 2002, Tolle, 2005, Mooji 2012). The present study aims to examine how openness to new experience changes in tourists. Although transformational power of tourism has been discussed in the literature (Lean, 2009), research into how openness to new experience (hereafter OTNE) changes in tourists is sporadic (Schneider \& Vogt, 2012, Jani, 2014). The transformative nature of certain tourism contexts and a possibly elevated level of openness of tourists seem to be a highly synergic combination for learning mindfulness skills.

\subsection{Tourism and Sustainability}

The unsustainable nature of international mass tourism and the need for possible degrowth of the industry has been reflected upon by several authors (Hall, 2009, Aall, 2014, Hollenhorst, Houge-Mackenzie \& Ostergren, 2014). Due to mainly the exponentially increasing number of long-haul trips, tourism's share of GHG emission in 2005 was estimated to be between 5-8 \% (UNWTO-UNEP-WMO, 2008). Taking into account the growth in international arrivals between 2005-2015 tourism-related emission might be well over $10 \%$ of global emission and according to some forecasts it can reach as much as $40 \%$ by 2050 (Dubois \& Ceron, 2006). Technological innovation resulting in less fuel consumption per seat kilometer might reduce aviation-related GHG emission by an estimated $25 \%$ by 2050 (Peeters, Gössling \& Becken, 2006), which is far from sufficient considering the urgency of the climate problem.

\subsection{Tourism and Wellbeing}

Although leisure travel has been found to have a positive effect on life satisfaction and happiness in both cross-sectional and longitudinal studies (Puczkó \& Smith 2001, Gilbert \& Abdullah, 2004, Nawijn, Miquelle, Marchand, Veenhoven, \& Vingerhoets, 2010, Michalkó, Kiss, Kovács, \& Sulyok, 2009, Veenhoven, 2011) as Nawijn points out in his study " Still, it is not established that this correlation is due to an effect of holiday trips on happiness or an effect of happiness on holiday-taking." (Nawijn, 2012: 37). Even if a small positive correlation has been confirmed, vacations do not have a lasting effect on wellbeing. The fade-out period can be a 
few days (De Bloom, Radstaak, \& Geurts, 2014) and 2-4 weeks in other studies (Nawijn, Miquelle, Marchand, Veenhoven, \& Vingerhoets, 2010, Kühnel \& Sonnentag, 2011). The present paper gives new empirical evidence of the fast fade-out of both positive physical and psychological effects of holidays. In one of the subprograms of the comprehensive government strategy (New Szechenyi Plan) titled Curing Hungary Health Industrial Program (Mirror translation of Gyógyító Magyarország Egészségipari Program) health oriented domestic tourism is expected to be vital in improving the health of the Hungarian population. Considering the average number and length of holidays taken by Hungarians (Eurostat, 2014) and the very short fade-out period of vacations, a significant improvement in life satisfaction and health through tourism cannot reasonably be expected. This statement seems to be supported by the fact that while domestic guest nights had doubled since 1991 in Hungary, many of the OECD health indicators of stress-related illnesses do not show any improvement. In 2000 out of 26 OECD countries Hungary ranked 2. for cardiovascular mortality and 23. for self-reported health status. In 2011 it was still ranked 2. for cardiovascular mortality and 30. for self-reported health status out of 33 countries. For cancer mortality it had retained its 1. place during the 10 year period (OECD, 2003, 2013).

\subsection{Mindfulness in Tourism}

Many of the mindfulness techniques have been part of the service portfolios of spa, wellness and ecotourism service providers around the world for several years (Lehto, Brown, Chen, \& Morrison 2006, Voigt, Brown \& Howat, 2011). According to SpaFinder's 2014 trend report mindfulness was labeled "Über Trend", that is the strongest trend in the spa and wellness industry. In 2015 the number one trend reported by SpaFinder was "Forest bathing" which also includes mindfulness type practices. Personal and spiritual growth, mind-body balance, alternative therapies (GWI, 2013), inner wellness (CBI, 2014) have been an integral and growingly significant part of the wellness paradigm. In spite of these global trends, out of the 2312 commercial accommodation service providers (2015 figure by KSH, the Central Statistical Office of Hunagry) in Hungary, approximately 18 offer some type of mindfulness service as part of their wellness portfolio. The present paper makes a reinforcing contribution to the previously cited demand side trends by analyzing Google Trends data about „mindfulness”.

\subsection{Formulation of Research Questions}

Based on what has been discussed so far and extending on previous research of the author (Lengyel, 2015) the empirical research of the present study attempts to find answers to the following research questions:

1) Do tourists (because of being a tourist) become significantly more open to new experience?

2) Are potential Hungarian wellness and ecotourists interested in trying mindfulness services?

3) Which type of tourism locations or establishments are best for learning mindfulness skills?

4) What are the trends for search terms connected with mindfulness globally?

5) What are the trends for search terms connected with mindfulness in the case of major tourist sending countries of Hungary?

6) What is the average fade-out period of positive physical and psychological effects of vacations?

\section{Method}

The primary research was based on two pillars. Google Trends data was analyzed to find answers for research questions 4 and 5, while questions 1, 2, 3, 6 were dealt with through using online surveys. Both approaches extend on and discuss in detail earlier research of the author carried out in March 2015 and summarized briefly in a conference proceedings of an international management conference titled ICOM organized by Szent István University, Hungary (Lengyel, 2015). This paper discusses in detail those parts of the earlier research which have either not been reflected upon at all in the proceedings paper or were presented without much detail. The sample surveyed in March 2015 will be referred to as S1 while the sample surveyed in June 2015, S2. There are three reasons why only potential Hungarian wellness and ecotourists were targeted with the surveys. The first concerns the availability of a large enough sample of potential wellness and ecotourists. The second is connected to the pressing challenge posed by an extremely unhealthy Hungarian population. Thirdly, as sustainability issues concerning aviation-based international tourism become more and more pressing, domestic tourism will probably gain new significance (Peeters \& Dubois, 2010). Within the country several shorter trips are affordable for a much broader portion of the population with significantly lower emission levels and higher level of positive wellbeing effects (Nawijn, 2012).

\subsection{Online Surveys}

\subsubsection{Participants}

Taking into account that the most likely consumer of mindfulness related tourism services in Hungary is the 
wellness or ecotourist, the main criterion in choosing the participants of the survey was the strong similarity between the samples' demographic characteristics and that of the typical wellness tourist (Lehto, Brown, Chen, \& Morrison 2006, Mak, Wong \& Chang, 2009, Voigt, Brown, \& Howat, 2011) or ecotourist (Galley \& Clifton, 2004, Wearing \& Neil, 2009, do Paço, Alves, \& Nunes, 2012). Table 1. shows demographic characteristics of S1, S2 and that of the typical wellness and ecotourist.

Table 1. Demographic characteristics of the research samples and "typicals" in literature

\begin{tabular}{ccccc}
\hline Demogr. variables & Gender & Age & Education & Income \\
\hline $\mathbf{S 1}(\mathrm{n}=999)$ & female $=83 \%$ & $>30=88 \%$ & $\mathrm{BA} / \mathrm{MA} / \mathrm{PhD}=87 \%$ & $>$ average $=71 \%$ \\
\hline S2 $(\mathrm{n}=548)$ & female $=68 \%$ & $>30=82 \%$ & $\mathrm{BA} / \mathrm{MA} / \mathrm{PhD}=78 \%$ & $>$ average $=50 \%$ \\
\hline $\begin{array}{c}\text { Typical wellness } \\
\text { tourist in literature }\end{array}$ & majority female & above 30 & $\begin{array}{c}\text { College and } / \text { or university } \\
\text { degree }\end{array}$ & above average \\
\hline $\begin{array}{c}\text { Typical ecotourist } \\
\text { in literature }\end{array}$ & majority female & above 30 & $\begin{array}{c}\text { College and/or university } \\
\text { degree }\end{array}$ & above average \\
\hline
\end{tabular}

Considering the four chosen demographic variables (gender, age, education, income) the demographic profile of wellness tourists and ecotourists is basically the same.

\subsubsection{Sampling Procedure}

As it would have been unfeasible to directly survey a big enough sample of visitors at wellness establishments, participants with demographic characteristics matching the demographic profile of typical wellness or ecotourists described by the literature were targeted. Surveys for both S1 and S2 were online surveys conducted through the Online Research Portal of Szent István University using Limesurvey for creating the questionnaire and managing responses. In the case of S1 headmasters of nursery, primary and secondary schools were asked to participate. There are three reasons why they were chosen as one of the target populations. Firstly, their demographic profile was supposed to be similar to the profiles of typical wellness or eco tourists. Secondly, a database containing the contact information of all nursery, primary and secondary school leaders in Hungary was publicly accessible. Thirdly, schools can play a significant role in changing children's attitude towards the environment (Stone \& Center for Ecoliteracy, 2009, Barr, Cross \& Dunbar, 2014,) and also in raising their level of mindfulness (Tadlock-Marlo, 2011). Altogether 6218 e-mails with a link to the online survey were sent out in March 2015 to all the leaders of nursery, primary and secondary schools. Until June 1st 20151483 questionnaires were sent back, 999 fully completed, which means a response rate of $16,1 \%$. At a confidence level of $99 \%$ and error level of $3,7 \% \mathrm{~S} 1$ is representative of the country's primary and secondary school leaders. S2 was gathered in June 2015 using the snowball method. Initially 89 individuals, whose demographic profile was (gender, age, education, income) similar to the typical wellness and ecotourist, were sent the link of the same questionnaire as in the case of S1 using the online research platform of Szent István University. Together with the link to the site of the questionnaire they also received a short message asking them to pass the link on to people who they were sure to possess demographic features (gender, age, education, income) similar to theirs. Out of the 1043 questionnaires sent back until July 1 2015, 548 were fully completed ones.

\subsubsection{Measures}

Both S1 and S2 received the same questionnaire containing 40 questions in the following areas: Effects of holidays and travelling habits. Sustainable attitude and behavior. Mindfulness knowledge, experience and level. Demographic features. Participants were informed that the questionnaire was anonymous and part of the author's $\mathrm{PhD}$ research at Szent István University. Respondents had the option of deleting their answers at any point in the answering process. Different types of questions were used to map respondents' opinion of the four research areas. The question whether tourists become more open to new experience while on vacation, compared to how open they were in everyday life, was measured by a 5-point rating item where the endpoints of the scale were explained as "No, not at all" and "Yes, a lot". How likely they were to try mindfulness type methods if available where they were staying, was tested using a 0-100 \% slide bar. A ranking order question was used to find out what types of tourism locations they considered best for learning mindfulness. The five options to be ranked were "Church", "Wellness location" (e.g. a meditation room of a wellness hotel or spa), "Nature location" (e.g. forest, river shore), "Village tourism location" (e.g. garden or room of a cottage), "Urban location" (e.g. a quiet 
square). Finally, the fade out periods of positive physical and psychological effects of a vacation were tested separately with a type box where the respondents entered the number of days the positive effect was felt after returning home. Derived datasets were created from S1 and S2 by keeping cases which had demographic properties (gender, age, education, income) identical to what was specified for the typical wellness and ecotourist. The new datasets (subsamples) are marked as S1w and S2w and account for 777 cases (77\%) and 301 cases $(55 \%)$ of the original datasets respectively.

\subsection{Google Trends Data Analysis}

Google Trends data have been proved to be a valuable source for statistical analysis (Carneiro \& Mylonakis , 2009, Lui, Metaxas, \& Mustafaraj, 2011, Choi \& Varian, 2012, Preis, Moat \& Stanley, 2013). To find answers to research questions 4 and 5, Google Trends time series data in csv format was downloaded for search terms likely to be used when one is interested in mindfulness. Search terms to be tested were selected using hints for top searches by Google Trends, keywords suggestions by the Google Addwords Keywords Tool and based on own search experience. 78 search terms related to mindfulness were tested both for the internet and You Tube. Plurals and reordered versions of search terms were also tested where applicable, but only variations yielding different search intensity trends are displayed separately. For major tourist sending countries of Hungary only the search intensity of the term "mindfulness" was examined. Regression analyses were performed to fit trend lines to the data.

\section{Results and discussion}

\subsection{Online surveys}

\subsubsection{Openness to New Experience}

Figure 4. shows how OTNE changes in potential wellness and ecotourists as compared to their OTNE in their everyday circumstances at home. The survey question was: „When you travel for pleasure, do you become more open to new experience than you are in your everyday life?" The endpoints and the middle point of the scale were: 1 - No, not at al; 3 - Yes, a bit; 5 - Yes, a lot.

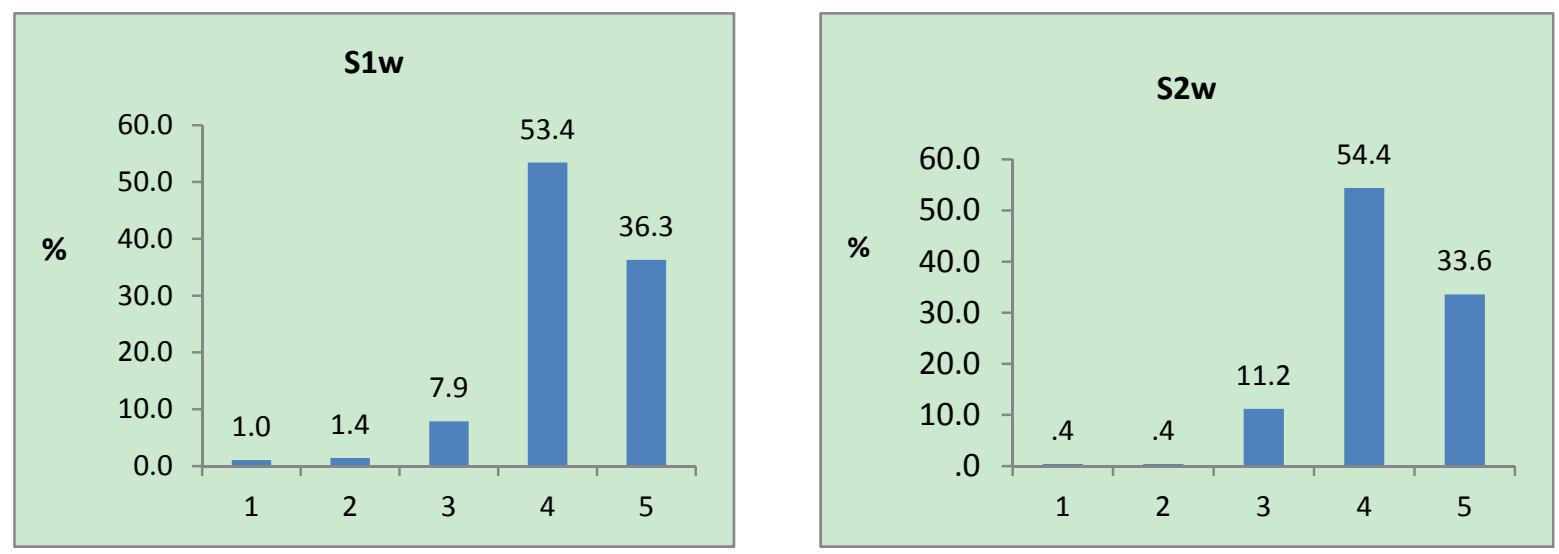

Figure 4. Openness to new experience changes in potential wellness and ecotourists

An affirmative answer can be given to research question 1. 97,6\% of respondents in S1w and 99,2\% in S2w think that they become more open to new experience while being tourists. Out of these, $89,7 \%$ (S1w) and $88 \%$ $(\mathrm{S} 2 \mathrm{w})$ felt that they become markedly more open to new experience while being on vacation. The mean values were 4,23 (S1w) and 4,20 (S2w). To decide whether parametric methods were applicable Levene's test for homogeneity of variance and Shapiro-Wilk test for normality was performed on the two subsamples of ordinal level data. The Shapiro-Wilk test was significant at $\mathrm{p}=0,000$ for both $\mathrm{S} 1 \mathrm{w}$ and $\mathrm{S} 2 \mathrm{w}$, consequently neither can be considered normally distributed. The Levene's test resulted in $\mathrm{F}=0,725$ and $\mathrm{p}=0,395$, which indicates equal variance. As parametric methods like t-test or ANOVA assume both normality and homogeneity of variance, the Mann-Whitney U-test was used to test whether there is a significant difference between S1w and S2w. The results, $Z=-0,885, p=0,376$ and the mean ranks $522,75(\mathrm{~S} 1 \mathrm{w})$ and $505,78(\mathrm{~S} 2 \mathrm{w})$ suggest that there is no statistically significant difference between the two groups in terms of OTNE. In order to test correlation between OTNE, demographic variables (age, education, income), length of positive physical and psychological effects and the willingness to try mindfulness services in the destination Kendall's tau-b test was run for the pairs of variables. OTNE and willingness to try mindfulness services showed very week correlation $\tau_{\mathrm{b}}=0.088, p=0.002$ 
in $\mathrm{S} 1 \mathrm{w}$, in $\mathrm{S} 2 \mathrm{w}$ the test was not significant $(\mathrm{p}=0,175)$. OTNE also showed weak positive correlation with the fade-out of positive physical $\left(\tau_{\mathrm{b}}=0.065, p=0.037\right)$ and psychological $\left(\tau_{\mathrm{b}}=0.064, p=0.032\right)$ effects in S1w while in $\mathrm{S} 2 \mathrm{w}$ the tests were not significant $(\mathrm{p}>0,05)$. In the case of the three demographic variables with the exception of OTNE-Income in S2w $\left(\tau_{\mathrm{b}}=-0.179, p=0.004\right)$ all tests were below significance level $(\mathrm{p}>0,05)$ in both subsamples $(\mathrm{S} 1 \mathrm{w}, \mathrm{S} 2 \mathrm{w})$. It is important to emphasize that although the two subsamples were drawn from rather different original samples (S1 - nationwide representative sample of primary and secondary school leaders, S2 - geographically more restricted snowball sample) they both exhibited the same significantly elevated level of OTNE as compared to everyday life. To put these OTNE values in perspective in Schneider and Vogt's study on hard and soft adventure tourists (Schneider \& Vogt, 2012) the mean values of openness to experience measured on a 9-point scale were 6,92 (HAT) and 6,38 (SAT). Transforming the mean values of S1w and S2w to the equivalent of a 9-point scale, the OTNE values are 7,61 and 7,56. It has to be underlined that while Schneider and Vogt measured what hard and soft adventure tourists thought about their openness to experience in everyday life, the present study measured how OTNE is changed in tourist as compared to everyday life. In Jani's study (Jani, 2014) mean openness is 3,204 measured on a 5-point scale. In his study domestic tourists on vacation were asked, but no reference is made whether the actual question concerned openness on vacation or in everyday life. There are important practical implications of these markedly high OTNE levels in potential wellness and ecotourists. In a demand-driven tourism market, mapping personality traits and behavior of potential customers is extremely important because it can help accommodation and destination managers, tour operators and site owners to develop products (e.g. mindfulness type services) suited to the psychological characteristics of the target audience. On the other hand, openness to experience is positively correlated with both pro-environmental behavior (Markowitz, Goldberg, Ashton, \& Lee, 2012) and mindfulness (Giluk, 2009, van den Hurk et al., 2011), thus the practice of mindfulness can help move the personality in a more environmental friendly direction.

\subsubsection{Willingness to Try Mindfulness Based Services in Destination}

To test how likely potential wellness and ecotourists were to try mindfulness based services in the destination they were staying, a slide bar with percentage points from 0-100 was used. The mean likelihood values were $63,37 \%(\mathrm{~S} 1 \mathrm{w})$ and $63,58 \%$ (S2w), almost the same for the two subsamples. The Shapiro-Wilk test was significant at $\mathrm{p}=0,000$ for both $\mathrm{S} 1 \mathrm{w}$ and $\mathrm{S} 2 \mathrm{w}$, therefore the Mann-Whitney U-test was used to test whether there is a significant difference between $\mathrm{S} 1 \mathrm{w}$ and $\mathrm{S} 2 \mathrm{w}$ in terms of willingness to try mindfulness services in the destination. Mean ranks were $482,73(\mathrm{~S} 1 \mathrm{w})$ and $491,71(\mathrm{~S} 2 \mathrm{w}), \mathrm{Z}=-0,400, \mathrm{p}=0,689$, which means that the likelihood of trying mindfulness products is not different in the two subsamples. The above percentage values are significantly high to be factored in when considering development of mindfulness type services for the destination or accommodation. They might, however, seem a bit low compared to the high levels of OTNE discussed in the previous subchapter. A possible explanation is the relatively low public awareness of mindfulness. Google Trends does not provide analyzable data for „mindfulness” for Hungary, whereas „meditáció" (Hungarian for „meditation”) has had a rising popularity since 2009. This low public awareness might in part be due to the fact that it is impossible to find a peer-reviewed article about mindfulness written by Hungarian researchers either in Hungarian or English on Google. By using effective promotional tools, emphasizing the accumulated scientific evidence on and proven benefits of mindfulness, these likelihood figures might be considerably raised.

\subsubsection{Ranking Tourism Locations for Suitability of Learning Mindfulness}

No research has so far been carried out into what tourism locations are best for mindfulness. The results are shown in Figure 5. By visual inspection it seems obvious that ranking patterns are very similar in the two subsamples $(\mathrm{S} 1 \mathrm{w}, \mathrm{S} 2 \mathrm{w})$. 

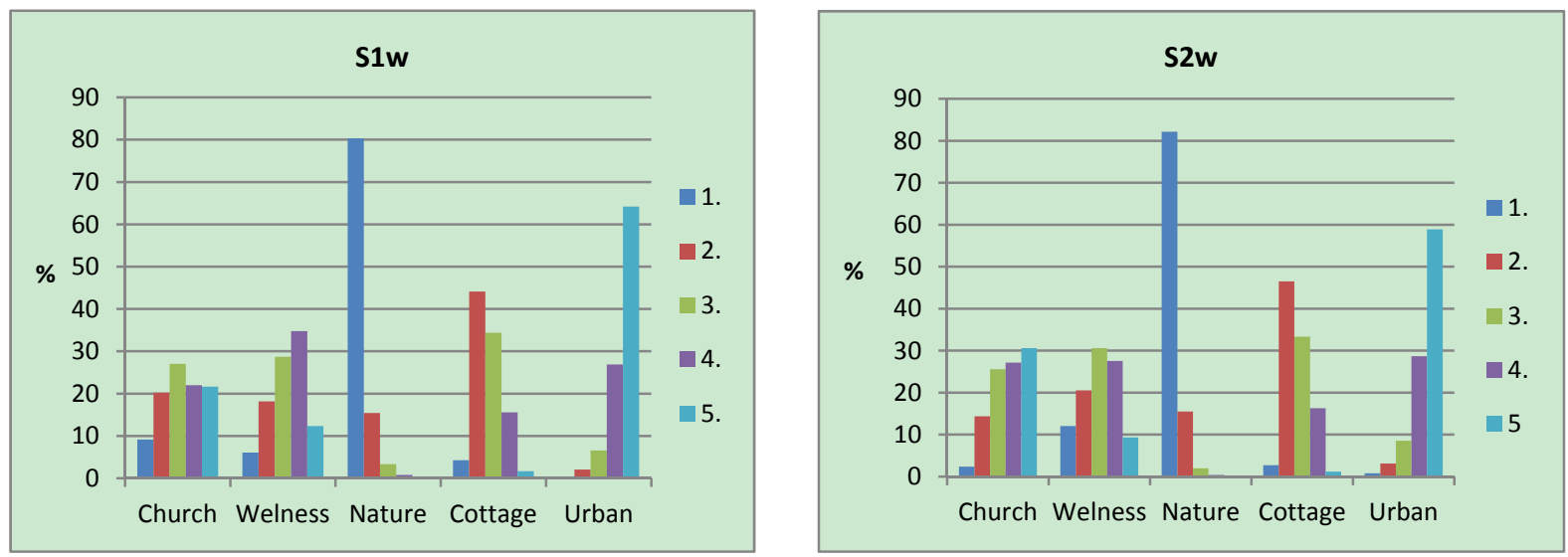

Figure 5. Rankings of tourism locations 1.-5. for suitability of learning mindfulness

Ranked in the first place far ahead of all other categories is Nature tourism locations in both subsamples, $80,3 \%$ (S1w), 82,2\% (S2w), while Urban tourism locations were mostly ranked last, 64,2\% (S1w) 58,9\% (S2w). 44,1\% of S1w and $46,5 \%$ of S2w thought Cottage (village) tourism locations are the second best for learning mindfulness. Wellness tourism locations were ranked 1 . by only $6 \%(\mathrm{~S} 1 \mathrm{w})$ and $12 \%(\mathrm{~S} 2 \mathrm{w})$ and ranked 2 . by $18,1 \%$ (S1w) and 20,5\% (S2w). Church locations were ranked 1 . by $9,1 \%$ and 2 . by 20,2\% in S1w which are higher than first and second rank percentages for Wellness locations in the same subsample. In S2w only 2,3\% ranked Church locations in the first place and $14,3 \%$ in the second. As none of the rank categories in the two subsamples were normally distributed (Shapiro-Wilk test, $\mathrm{p}=0,000$ ) they were compared by Mann-Whitney U-test to see if there was a significant difference in rank choices. For ranking group 1. (items ranked first) $Z=-0,326, p=0,745$, for group 2. $Z=-1,511, p=0,131$, for group $3 . Z=-0,455, p=0,649$, fro group $4 . Z=-0,249, p=0,803$, for group 5 . $\mathrm{Z}=-2,089, \mathrm{p}=0,037$. Except for ranking group 5 there is no significant difference between $\mathrm{S} 1 \mathrm{w}$ and $\mathrm{S} 2 \mathrm{w}$ in terms of how participants ranked the 5 different tourism locations for suitability of learning mindfulness. Both ecotourism and village tourism are prioritized forms of tourism in Hungary in the National Tourism Development Concept 2014-2024. Also, these forms are considered sustainable options in tourism literature provided that certain precautions are taken by host communities (Krüger, 2005, Fons, Fierro, \& Patiño, 2011, Salazar, 2012). This favorable constellation of government intentions, demand side preferences and sustainable tourism forms should be seriously considered by decision makers involved in tourism product development.

\subsubsection{Fade-out Period of Positive Physical and Psychological Effects}

The mean fade-out for positive physical effects for $\mathrm{S} 1 \mathrm{w}$ is 11,2 days while the mean fade-out value for positive psychological effects is 24,2 days. In the case of S2w the mean values for the same variables are 8,3 days and 18,6 days respectively. The Shapiro-Wilk test was significant at $\mathrm{p}=0,000$ for both $\mathrm{S} 1 \mathrm{w}$ and $\mathrm{S} 2 \mathrm{w}$ for both positive physical and psychological effects data, consequently the Mann-Whitney U-test was used. The results, $\mathrm{Z}=-3,510$, $\mathrm{p}=0,000$ (positive physical effects) and $\mathrm{Z}=-4,222, \mathrm{p}=0,000$ (positive psychological effects) mean that there is statistically significant difference between the two subsamples (S1w,S2w) in terms of the length of positive physical and psychological effects of a vacation. In spite of the statistical difference between the two subsamples, the mean fade-out values support earlier literature on fade-out of positive vacation effects (Nawijn, Miquelle, Marchand, Veenhoven, \& Vingerhoets, 2010, Kühnel \& Sonnentag, 2011, De Bloom, Radstaak, \& Geurts, 2013,) and raise serious doubts about how much traditional tourism products in general and especially in Hungary can actually contribute to improving physical and psychological health of the population. Although happiness (subjective wellbeing) is positively correlated with good health (Veenhoven, 2007, Boehm \& Kubzansky, 2012, Sabatini, 2014), because of the very short fade-out period tourism's effect is very limited, if any at al.

\subsection{Google Trends}

In an earlier research of the author search trends for 110 search terms related to „meditation” were analyzed based on Google Trends data (Lengyel, 2015). $94 \%$ of meditation-related terms for the internet and 63\% for YouTube have had continuously rising search intensity at least for the last three years. The word „meditation” (in countries' own language) has also had an upward search intensity trend on the internet in the case of major tourist sending countries of Hungary for the last few years (Germany 2010, Austria 2012, UK 2010, Russia 2012, Italy 2013, USA 2011). For the present study the search intensity changes of 78 search terms containing the 
words „mindful” or „mindfulness” were examined for Google and YouTube. Out of the 78 terms for the following 17 Google Trends yielded no sufficient data either for Google or YouTube to be analyzed:

learn mindfulness, mindful office, mindful way of life, mindfulness advice, mindfulness blood pressure, mindfulness concentration, mindfulness corporate, mindfulness everybody, mindfulness focus, mindfulness method, mindfulness steps, mindfulness technique, mindfulness tips, mindfulness tourism, mindfulness wellness, mindfulness spa, office mindfulness

Google Trends provided analyzable data for the following 61 terms:

benefits mindfulness, do mindfulness, guided mindfulness meditation, how mindfulness, meditation mindfulness, mindful life, mindful living, mindful therapy, mindful way, mindful work, mindfulness, mindfulness and anxiety, mindfulness and depression, mindfulness and meditation, mindfulness and stress, mindfulness anxiety, mindfulness based cognitive therapy, mindfulness based stress reduction, mindfulness based therapy, mindfulness benefits, mindfulness book, mindfulness books, mindfulness business, mindfulness center, mindfulness children, mindfulness cognitive therapy, mindfulness course, mindfulness depression, mindfulness exercise, mindfulness for anxiety, mindfulness for depression, mindfulness group, mindfulness groups, mindfulness guide, mindfulness guided, mindfulness health, mindfulness help, mindfulness how to, mindfulness jon kabat zinn, mindfulness kabat, mindfulness kabat zinn, mindfulness meditation, mindfulness music, mindfulness online, mindfulness practice, mindfulness school, mindfulness stress, mindfulness stress reduction, mindfulness teacher, mindfulness techniques, mindfulness therapy, mindfulness training, mindfulness video, mindfulness work, mindfulness yoga, mindfulness you, online mindfulness, practice mindfulness, what is mindfulness, what mindfulness, why mindfulness

Out of the above 61 terms, in YouTube searches only 3 (mindfulness, mindfulness meditation, guided mindfulness meditation) yielded analyzable data. As for Google searches all 61 (100\%) examined search terms have had a steady upward search intensity trend for at least the last two years. $82 \%$ (50 items) of the sample has had a rising trend for at least 3 years, and 57\% (35 items) for at least the last 4 years. Due to restrictions concerning the length of this paper Figure 6. shows trends only for "mindfulness" on Google and YouTube in recent years.
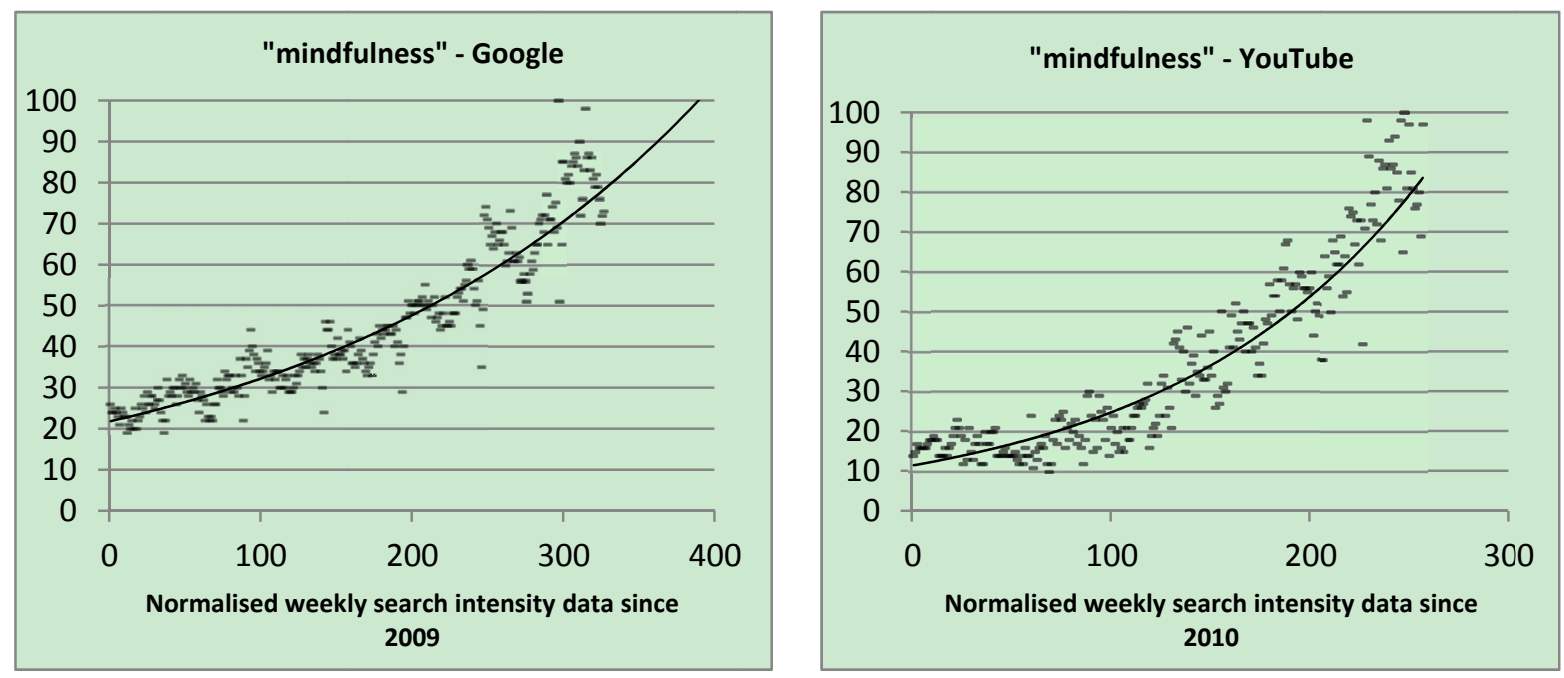

Figure 6. Relative popularity of „mindfulness on” a 1-100 scale based on Google Trends data

For both Google and YouTube search data on „mindfulness” exponential regression yielded the best fit line. It should be noted that popularity of the search terms ",meditation” and ,yoga" have also been rising exponentially since 2010. Table 2. shows how the popularity of the search term ,mindfulness" have been changing in the last few years in the six major tourist sending countries of Hungary in Google and YouTube. Guest night percentages of each country are also displayed. 
Table 2. Popularity of ,mindfulness" in major tourist sending countries of Hungary in recent years

\begin{tabular}{ccccccc}
\hline Country/guest & Germ. & Aust. & UK & Russ. & Ita. & USA \\
night \% & $\mathbf{1 7 \%}$ & $\mathbf{7 \%}$ & $\mathbf{6 \%}$ & $\mathbf{6 \%}$ & $\mathbf{5 \%}$ & $\mathbf{4 \%}$ \\
\hline Google & $\uparrow$ since & nsd & $\uparrow$ since & nsd & $\uparrow$ since & $\uparrow$ since \\
& 2011 & & 2008 & & 2011 & 2006 \\
\hline YouTube & nsd & nsd & $\uparrow$ since & nsd & msd & $\uparrow$ since \\
& & & 2012 & & & 2011 \\
\hline
\end{tabular}

Note. nsd $=$ no sufficient data

Similarly to the term „meditation” (Lengyel, 2015) the popularity of the search term „mindfulness” has been growing in all of the major tourist sending countries of Hungary for which sufficient data was available in Google Trends.

There are several limitations that restrict the generalisability of the results. Although the combined samples are relatively big $(\mathrm{S} 1+\mathrm{S} 2=1547, \mathrm{~S} 1 \mathrm{w}+\mathrm{S} 2 \mathrm{w}=1078)$ and one of the samples (S1) is representative of the subpopulation, both samples $(\mathrm{S} 1, \mathrm{~S} 2)$ are samples of convenience and thus do not give a statistically comprehensive representation of Hungary's potential wellness and ecotourists. Also, S1 is a sample that is completely homogeneous in terms of the profession of the participants. However, this concern is somewhat downplayed by the fact that S1w and S2w demonstrated very similar statistical properties for all the examined variables. It supports the initial assumption that the chosen 4 demographic variables largely determine attitudes and certain personality traits of potential wellness and ecotourists. This research was exploratory in the sense that none of the research questions it attempted to answer have been dealt with so far by peer-reviewed literature in Hungary. Future research might extend to mapping OTNE changes, tourism location preferences for mindfulness instruction, willingness to try mindfulness products for actual domestic and incoming wellness and ecotourists. The measure could be largely improved by using probability sampling methods that ensure broader generalisability and can either support or contradict the present research findings. Fade-out research can also be taken further, however, it is an area that have been researched extensively and the results of the present research are in harmony with earlier findings.

\section{Conclusion}

The present study lined up empirical evidence to prove that because of the significantly raised level of openness to new experience (OTNE) in tourists the tourism context, especially nature based and village tourism locations seem to be ideal for learning mindfulness while on vacation. Although the samples in the empirical research covered only potential Hungarian wellness and ecotourists, evidence obtained from Google Trends analyses for mindfulness clearly demonstrated that there is a strong and rising interest in mindfulness both globally and for major tourist sending countries of Hungary. It provides a business case for developing and launching mindfulness type tourism products for incoming tourists as well. Extending tourism's role in popularizing and teaching mindfulness should, however, be priority in developing mindfulness products for domestic tourists if tourism is to genuinely contribute to improving physical and psychological wellbeing of the extremely unhealthy Hungarian population. According to Matrix a study funded by the Health Programme of the European Union, the estimated cost of work-related depression amounts to 620 billion Euros in the EU27 annually (Matrix, 2013), an amount six times bigger that the Hungarian GDP in 2013. As there is massive clinical evidence for the effectiveness of mindfulness in reducing stress levels, political decision makers should seriously consider the possibility of providing government support to tourism service providers who are willing to offer mindfulness services to tourists. As mindfulness has positive effects on sustainable behavior (Jacob, Jovic, \& Brinkerhoff, 2008, Amel, Manning, \& Scott, 2009, Rosenberg, 2004, Brown, \& Kasser, 2005) mindfulness based tourism services could serve as a form of long-term carbon offsetting for the tourism industry.

\section{Acknowledgements}

The author would like to express his gratitude for the support provided by Szent István University in the form of granting access to the online research platform and last but not least for the kind help given by participants completing questionnaires for the empirical research.

\section{References}

Aall, C. (2014). Sustainable Tourism in Practice: Promoting or Perverting the Quest for a Sustainable 
Development? Sustainability, 6(5), 2562-2583. http://dx.doi.org/10.3390/su6052562

Amel, E. L., Manning, C. M., \& Scott, B. A. (2009). Mindfulness and Sustainable Behavior: Pondering Attention and Awareness as Means for Increasing Green Behavior, Ecopsychology, 1(1), 14-25. http://dx.doi.org/10.1089/eco.2008.0005.

Amiable, T. M. (1997). Motivating creativity in organizations: On doing what you love and loving what you do. California Management Review, 40(1), 39-58. http://dx.doi.org/10.2307/41165921

Baer, R. A., Smith, G. T., Hopkins, J., Krietemeyer, J., \& Toney, L. (2006). Using self-report assessment methods to explore facets of mindfulness. Assessment, 13, 27-45. http://dx.doi.org/10.1177/1073191105283504

Barr, S., Cross, J., \& Dunbar, B. (2014). The Whole School Sustainability Framework. Retrieved from Institute for the Built Environment at Colorado State University website: http://centerforgreenschools.org/Libraries/Publications/Whole-School_Sustainability_Framework.sflb.ashx

Baudrillard, J. (1998). The Consumer Society: Myths and Structures. London: Sage. Retrieved from http://cnqzu.com/library/Economics/marxian\%20economics/Baudrillard,\%20Jean-The\%20Consumer\%20S ociety.Myths\%20and\%20Structures.pdf

Bishop, S. R., Lau, M., Shapiro, S., Carlson, L., Anderson, N. D., Carmody, J., ... Devins, G. (2004). Mindfulness: A proposed operational definition. Clinical Psychology: Science and Practice, 11(3), 230-241. http://dx.doi.org/10.1093/clipsy.bph077

Black, D. S. (2014). Mindfulness-based interventions: An antidote to suffering in the context of substance use, misuse, and addiction. Substance Use \& Misuse, 49(5), 487-91. http://dx.doi.org/10.3109/10826084.2014.860749

Boehm, J. K., \& Kubzansky, L. D. (2012, April 16). The Heart's Content: The Association Between Positive Psychological Well-Being and Cardiovascular Health. Psychological Bulletin. Advance online publication. http://dx.doi.org/10.1037/a0027448

Brown, D. P., \& Engler, J. (1980). The Stages Of Mindfulness Meditation, A Validation Study. Journal of Transpersonal Psychology, 12(2), 143-149.

Brown, K. W., \& Ryan, R. M. (2003). The Benefits of Being Present: Mindfulness and Its Role in Psychological

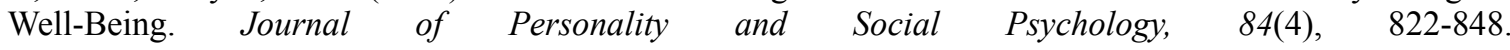
http://dx.doi.org/10.1037/0022-3514.84.4.822

Brown, K., \& Kasser, T. (2005). Are psychological and ecological wellbeing compatible? The role of values, mindfulness and lifestyle. Social Indicators Research, 74, 349-368. http://dx.doi.org/10.1007/s11205-004-8207-8

Capra, F. (1982). The Turning Point: Science, Society and the Rising Culture. New York: Simon and Schuster.

Carneiro, H. A., \& Mylonakis, E. (2009). Google Trends: a web-based tool for real-time surveillance of disease outbreaks. Clinical Infectious Diseases, 49, 1557-64. http://dx.doi.org/10.1086/630200

Carpenter, S. R., Cole, J. J., Pace, M. L., Batt, R., Brock, W. A., Cline, T., ... Weidel, B. (2011). Early warnings of regime shifts: A whole - ecosystem experiment. Science, 332(6033), 1079-1082. http://dx.doi.org/10.1126/science.1203672

CBI. (2014). CBI Product Fact Sheet Wellness tourism by EU residents. Retrieved from http://www.cbi.eu/sites/default/files/study/product-factsheet-wellness-tourism-europe-tourism-2013.pdf

Choi, H. Y., \& Varian, H. (2012). Predicting the present with Google Trends. Economic Record, 88, $2-9$. http://dx.doi.org/10.1111/j.1475-4932.2012.00809.x

Colzato, L. S., Ozturk, A., \& Hommel, B. (2012). Meditate to Create: The Impact of Focused-Attention and Open-Monitoring Training on Convergent and Divergent Thinking. Frontiers in Psychology, http://dx.doi.org/10.3389/fpsyg.2012.00116

Davidson, R. J., Kabat-Zinn, J., Schumacher, J., Rosenkranz, M., Muller, D., Santorelli, S. F., ... Sheridan, J. F. (2003). Alterations in brain and immune function produced by mindfulness meditation. Psychosomatic Medicine, 65, 564-570. http://dx.doi.org/10.1097/01.PSY.0000077505.67574.E3

De Bloom, J., Radstaak, M., \& Geurts, S. (2014). Vacation effects on behavior, cognition and emotions of compulsive and non-compulsive workers. Stress and Health, 30, 232-243. http://dx.doi.org/10.1002/smi.2600

Diamond, J. M. (2011). Collapse: How Societies Choose to Fail or Survive. London: Penguin.

do Paço, A., Alves, H., \& Nunes, C. (2012). Ecotourism from both Hotels and Tourists' Perspective. Economics 
\& Sociology, 5(2), 132-142. http://dx.doi.org/10.14254/2071-789X.2012/5-2/10

Dubois, G., \& Ceron, J. P. (2006). Tourism/leisure greenhouse gas emission forecasts for 2050: Factors for change in France. Journal of Sustainable Tourism, 14(2), 172-191. http://dx.doi.org/10.1080/09669580608669051

$\begin{array}{lllll}\text { Eurostat. } & \text { (2014). } & \text { Tourism } & \text { statistics. } & \text { Retrieved }\end{array}$ http://ec.europa.eu/eurostat/statistics-explained/index.php/Tourism_statistics

Fiol, C. M., \& O'Connor, E. J. (2003). Waking up! mindfulness in the face of bandwagons. The Academy of Management Review, 28, 54-70.

Fons, M. V. S., Fierro, J. A. M., \& Patiño, M. M. (2011). Rural tourism: A sustainable alternative. Applied Energy, 88, 551-557. http://dx.doi.org/10.1016/j.apenergy.2010.08.031

Galley, G., \& Clifton, J. (2004). The motivational and demographic characteristics of research ecotourists: Operation Wallacea volunteers in southeast Sulawesi, Indonesia. Journal of Ecotourism, 3, 69-82. http://dx.doi.org/10.1080/14724040408668150

Gaylord, S. A., Palsson, O. S., Garland, E. L., Faurot, K. R., Coble, R. S., Mann, J. D., ... Whitehead, W. E. (2011). Mindfulness training reduces the severity of irritable bowel syndrome in women: results of a randomized controlled trial. American Journal of Gastroenterology, 106, 1678-88. http://dx.doi.org/10.1038/ajg.2011.184

Gethin, R. (2011). On some definitions of mindfulness, Contemporary Buddhism, 12(1). http://dx.doi.org/10.1080/14639947.2011.564843

Gilbert, D., \& Abdullah, J. (2004). Holidaytaking and the Sense of Well-Being. Annals of Tourism Research, 31(1), 103-121. http://dx.doi.org/10.1016/j.annals.2003.06.001

Giluk, T. L. (2009). Mindfulness, Big Five personality, and affect: A meta-analysis. Personality and Individual Differences, 47(8), 805-811. http://dx.doi.org/10.1016/j.paid.2009.06.026

Gössling, S., Haglund, L., Kallgren, H., Revahl, M., \& Hultman, J. (2009). Swedish Air Travellers and Voluntary Carbon Offsets: Towards the Co-Creation of Environmental Value? Current Issues in Tourism, 12(1), 1-19. http://dx.doi.org/10.1080/13683500802220687

Grabovac, A. D., Lau, M. A., \& Willett, B. R. (2011). Mechanisms of Mindfulness: A Buddhist Psychological Model. Mindfulness. http://dx.doi.org/10.1007/s12671-011-0054-5

GWI. (2014). Global spa \& wellness economy monitor. Global Wellness Institute. Retrieved from http://mrot.pl/images/pliki/GWI_Global_Spa_and_Wellness_Economy_Monitor_Full_Report_pdf

Hall, C. M. (2009). Degrowing tourism: décroissance, sustainable consumption and steady-state tourism. Anatolia: An International Journal of Tourism \& Hospitality Research, 20, 46-61. $\mathrm{http}: / / \mathrm{dx}$. doi.org/10.1080/13032917.2009.10518894

Harvey, D. (2011). The enigma of capital and the crisis of capitalism. Oxford: Oxford University Press.

Herold, D. M., Davis, W., Fedor, D. B., \& Parsons, C. K. (2002). Dispositional influences on transfer of learning in multistate training programs. Personnel Psychology, 55(4), http://dx.doi.org/10.1111/j.1744-6570.2002.tb00132.x

Hollenhorst, S. J., Houge-Mackenzie, D. S., \& Ostergren, D. M. (2014). The Trouble with Tourism. Tourism Recreation Research, 39(3), 305-319. http://dx.doi.org/10.1080/02508281.2014.11087003

Holzel, B. K. Lazar, S. W., Gard, T., Schuman-Olivier, Z., Vago, D. R., \& Ott, U. (2011). How does mindfulness meditation work? Proposing mechanisms of action from a conceptual and neural perspective. Perspectives on Psychological Science, 6, 537-559. http://dx.doi.org/10.1177/1745691611419671

Hölzel, B. K., Carmody, J., Vangel, M., Congleton, C., Yerramsetti,S. M., Gard, T., \& Lazar, S. W. (2011). Mindfulness practice leads to increases in regional brain gray matter density. Psychiatry Research, 191, 3643. http://dx.doi.org/10.1016/j.pscychresns.2010.08.006

Horan, R. (2009). The Neuropsychological Connection Between Creativity and Meditation. Creativity Research Journal, 2l(2-3), 199-202. http://dx.doi.org/10.1080/10400410902858691

Hughes, J. W., Fresco, D. M., Myerscough, R., van Dulmen, M. H., Carlson, L. E., \& Josephson, R. Randomized controlled trial of mindfulness-based stress reduction for prehypertension. Psychosomatic Medicine, 75, 721-8. http://dx.doi.org/10.1097/PSY.0b013e3182a3e4e5

Hume, R. (1921). The Thirteen Principal Upanishads. Oxford University Press. Retrieved from http://oll.libertyfund.org/titles/2058 
Inspired times. (2012). Meeting $\quad$ Mooji. $\quad 12 . \quad$ Retrieved from http://www.inspiredtimesmagazine.com/Articles/Main\%20Pages/Resources/Meeting\%20Mooji.pdf

Jacob, J., Jovic, E., \& Brinkerhoff, M. B. (2008). Personal and Planetary Well-being: Mindfulness Meditation, Pro-environmental Behavior and Personal Quality of Life in a Survey from the Social Justice and Ecological Sustainability Movement. Social Indicators Research, 93(2), $275-294$. http://dx.doi.org/10.1007/s11205-008-9308-6

Jani, D. (2014). Relating travel personality to Big Five Factors of personality. Tourism, 62(4), 347-359.

Kabat-Zinn, J. (1982). An outpatient program in behavioral medicine for chronic pain patients based on the practice of mindfulness meditation: Theoretical considerations and preliminary results. General Hospital Psychiatry, 4, 33-47. http://dx.doi.org/10.1016/0163-8343(82)90026-3

Kabat-Zinn, J. (2003). Mindfulness-based interventions in context: Past, present, and future. Clinical Psychology: Science and Practice, 10(2), 144-156. http://dx.doi.org/10.1093/clipsy.bpg016

Kabat-Zinn, J., Lipworth, L., Burney, R., \& Sellers, W. (1987). Four-Year follow-up of a meditation-based program for the self-regulation of chronic pain: Treatment outcomes and compliance. Clinical Journal of Pain, 2(3), 159-173. http://dx.doi.org/10.1097/00002508-198602030-00004

Kriegler, E., Weyant, J. P., Blanford, G. J., Krey, V., Clarke, L., Edmonds, J., ... van Vuuren, D. P. (2014). The role of technology for achieving climate policy objectives: overview of the EMF 27 study on global technology and climate policy strategies. Climatic Change, 123, 353-367. http://dx.doi.org/10.1007/s10584-013-0953-7

Krüger, O. (2005). The role of ecotourism in conservation: panacea or Pandora's box? Biodiversity \& Conservation, 14(3), 579-600. http://dx.doi.org/10.1007/s10531-004-3917-4

Kühnel, J., \& Sonnentag, S. (2011). How long do you benefit from vacation? Journal of Organizational Behavior, 32, 125-143. http://dx.doi.org/10.1002/job.699

Le Quéré, C., Moriarty, R., Andrew, R. M., Peters, G. P., Ciais, P., Friedlingstein, P., ... Zeng, N. (2014). Global carbon budget 2014. Earth Systems Science Data, 7, 47-85. http://dx.doi.org/10.5194/essd-7-47-2015

Lean, G. L. (2009). Transformative Travel: Inspiring Sustainability. In R. Bushell, \& P. J. Sheldon (Eds.), Wellness and Tourism: Mind, Body, Spirit, Place (pp. 191-205). Elmsford, NY: Cognizant Communication.

Lehto, X. Y., Brown, S., Chen, Y., \& Morrison, A. M. (2006). Yoga tourism as a niche within the wellness tourism market. Tourism Recreation Research, 314. http://dx.doi.org/10.1080/02508281.2006.11081244

Lengyel, A. (2015). Extending tourism's role in the tourism - meditation - creativity-innovation - sustainability trajectory. Proceedings of the 5th Icom Conference of Szent István university, Gödölló, Hungary. http://dx.doi.org/10.17626/dBEM.ICoM.P00.2015.p100

Liu, M.-W. (1993). A Chinese Madhyamaka Theory of Truth: The Case of Chi-Tsang. Philosophy East and West, 43(4), 649-673. Retrieved from http://enlight.lib.ntu.edu.tw/FULLTEXT/JR-PHIL/ming1.htm

Lui, C., Metaxas, P. T., \& Mustafaraj, E. (2011). On the Predictability of the U.S. Elections through Search Volume Activity. Proceedings of the IADIS International Conference on e-Society, Avila, Spain.

Mak, A. H. N., Wong, K. K. F., \& Chang, R. C. Y. (2009). Health or self-indulgence? The motivations and characteristics of spa-goers. International Journal of Tourism Research, 2(11), $185-199$. http://dx.doi.org/10.1002/jtr.703

Markowitz, E. M., Goldberg, L. R., Ashton, M. C., \& Lee, K. (2012). Profiling the 'pro-environmental individual': A personality perspective. Journal of Personality, 80, 81-111. http://dx.doi.org/10.1111/j.1467-6494.2011.00721.x

Martinez-Alier, J., Pascual, U., Vivien, F., \& Zaccai, E. (2010). Sustainable de-growth: Mapping the context, criticisms and future prospects of an emergent paradigm. Ecological Economics, 69(9), 1741-1747. http://dx.doi.org/10.1016/j.ecolecon.2010.04.017

Matchim, Y., Armer, J. M., \& Stewart, B. R. (2011) Mindfulness-Based Stress Reduction Among Breast Cancer Survivors: A Literature Review and Discussion. Oncology Nursing Forum, 38(2), 61-71. http://dx.doi.org/10.1188/11.ONF.E61-E71

Matrix. (2013). Economic analysis of workplace mental health promotion and mental disorder prevention programmes and of their potential contribution to EU health, social and economic policy objectives. EU Health Programme 2008-2013. 
Michalkó, G., Kiss, K., Kovács, B., \& Sulyok, J. (2009). The impact of tourism on subjective quality of life among Hungarian population. Hungarian Geographical Bulletin, 58(2), 121-136.

Mikulas, W. L. (2011). Mindfulness: significant common confusions. Mindfulness, 2, 1-7. http://dx.doi.org/10.1007/s12671-010-0036-z

Mooji. (2012). Before I Am: The Direct Recognition of Truth - Dialogues with Mooji. Mooji Media.

Nath Hahn, T. (1999).The miracle of mindfulness. Beacon Press.

Nawijn, J. (2012). Leisure travel and happiness: An empirical study into the effect of holiday trips on individuals' subjective wellbeing. Erasmus University Rotterdam. Retrieved from http://repub.eur.nl/pub/32471

Nawijn, J., Miquelle, A., Marchand, M. A., Veenhoven, R., \& Vingerhoets, A. J. (2010). Vacationers Happier, but Most not Happier after a Holiday. Applied Research in Quality of Life. http://dx.doi.org/10.1007/s11482-009-9091-9

Nyanaponika. (1962). The heart of Buddhist meditation: A handbook of mental training based on the Buddha's way of mindfulness. London: Rider \& Company.

OECD. (2003). Health at a glance. OECD indicators. 2003. France: OECD Publication Services.

OECD. (2013). Health at a Glance 2013: OECD Indicators. OECD Publishing. http://dx.doi.org/10.1787/health_glance-2013-en

Osho. (1988). Great Zen Master Ta Hui: Reflections on the Transformation of an Intellectual to Enlightenment. Osho Intl.

Osho. (2002). Tao: The pathless path. Renaissance Books.

Parswani, M. J., Sharma, M. P., \& Iyengar, S. (2013). Mindfulness-based stress reduction program in coronary heart disease: A randomized control trial. International Journal of Yoga, 6(2), 111-117. http://dx.doi.org/10.4103/0973-6131.113405

Peeters, P. M., Gössling, S., \& Becken, S. (2006). Innovation Towards Tourism Sustainability: Climate Change and Aviation. International Journal of Innovation and Sustainable Development, 1(3), 184-200. http://dx.doi.org/10.1504/IJISD.2006.012421

Peeters, P., \& Dubois, G. (2010). Tourism travel under climate change mitigation constraints. Journal of Transport Geography, 18(3), 447-457. http://dx.doi.org/10.1016/j.jtrangeo.2009.09.003

Pepping, C. A., O’Donovan, A., \& Davis, P. J. (2014). The differential relationship between mindfulness and attachment in experienced and inexperienced meditators. Mindfulness, 5, 392-399. http://dx.doi.org/doi:10.1007/s12671-012-0193-3

Polimeni, J., Mayumi, K., Giampietro, M., \& Alcott, B. (2007). The Jevons Paradox and the Myth of Resource Efficiency Improvements. London: Earthscan

Preis, T., Moat, H. S., \& Stanley, H. E. (2013). Quantifying Trading Behavior in Financial Markets Using Google Trends. Scientific Reports, 3(1684). http://dx.doi.org/10.1038/srep01684

Puczko, L., \& Smith, M. (2001). Tourism- specific quality- of- life index: The Budapest model. In M. Budruk, \& R. Phillips (Eds.), Quality-of-life community indicators for parks, recreation and tourism. Springer.

Randers, J. (2012). A global forecast for the next forty years. In The Future in Practice: The State of Sustainability Leadership 2012. University of Cambridge.

Reb, J., Narayanan, J., \& Ho, Z. W. (2013). Mindfulness at Work: Antecedents and Consequences of Employee Awareness and Absent-mindedness. Mindfulness, 6(1). Retrieved from http://ink.library.smu.edu.sg/lkcsb_research/3541

Ren, J., Huang, Z., Luo, J., Wei, G., Ying, X., Ding, Z., ... Luo, F. (2011). Meditation promotes insightful problem-solving by keeping people in a mindful and alert conscious state. Science China Life Science, 54, 961-965. http://dx.doi.org/10.1007/s11427-011-4233-3

Rosenberg, E. L. (2004). Mindfulness and consumerism. In T. Kasser, \& A. D. Kanner (Eds.), Psychology and Consumer Culture: The Struggle for a Good life in a Materialistic world (pp. 107-125). American Psychological Association, Washington. http://dx.doi.org/10.1037/10658-007

Sabatini, F. (2014). The relationship between happiness and health: Evidence from Italy. Social Sciences Media, 114, 178-187. http://dx.doi.org/10.1016/j.socscimed.2014.05.024

Salazar, N. B. (2012). Community-based Cultural Tourism: Issues, Threats and Opportunities. Journal of 
Sustainable Tourism, 20, 9-22. http://dx.doi.org/10.1080/09669582.2011.596279

Scheffer, M., Carpenter, S., Foley, J. A., Folke, C., \& Walker, B. H. (2001). Catastrophic shifts in ecosystems. Nature, 413, 591-596. http://dx.doi.org/10.1038/35098000

Schneider, P., \& Vogt, C. (2012). Applying the 3M Model of Personality and Motivation to Adventure Travellers. Journal of Travel Research, 51(6), 704-716. http://dx.doi.org/10.1177/0047287512451134

Schumacher, E. F. ('973). Small is beautiful; economics as if people mattered. New York, Harper \& Row.

Sephton, S. E., Salmon, P., Weissbecker, I., Ulmer, C., Floyd, A., Hoover, K., \& Studts, J. L. (2007). Mindfulness meditation alleviates depressive symptoms in women with fibromyalgia: results of a randomized clinical trial. Arthritis \& Rheumatism, 57, 77-85. http://dx.doi.org/10.1002/art.22478

Steffen, W., Richardson, K., Rockström, J., Cornell, S. E., Fetzer, I., Bennett, E. M., ... Sörlin, S. (2015). Planetary boundaries: Guiding human development on a changing planet. Science, 347, 6219. http://dx.doi.org/10.1126/science.1259855

Sterman, J. D., \& Sweeney, L. B. (2007). Understanding Public Complacency About Climate Change: Adults' Mental Models of Climate Change Violate Conservation of Matter. Climatic Change, 80(3), 213-238. http://dx.doi.org/10.1007/s10584-006-9107-5

Stone, M. K., \& Center for Ecoliteracy. (2009). Smart by nature: Schooling for sustainability (1st ed.). Healdsburg, CA: Watershed Media.

Tadlock-Marlo, R. L. (2011). Making minds matter: Infusing mindfulness into school counseling. Journal of Creativity in Mental Health, 6(3), 220-233. http://dx.doi.org/10.1080/15401383.2011.605079

Tolle, E. (2005). The Power of Now. Hodder Mobius.

UNWTO-UNEP-WMO. (2008). Climate Change and Tourism: Responding to Global Challenges. Madrid: UNWTO

Urry, J. (2010). Sociology and climate change. The Sociological Review, 57, 84-100. http://dx.doi.org/10.1111/j.1467-954X.2010.01887.x

van den Hurk, P. A., Wingens, T., Giommi, F., Barendregt, H. P., Speckens, A. E., \& van Schie, H. T. (2011). On the relationship between the practice of Mindfulness Meditation and personality: An exploratory analysis of the mediating role of Mindfulness skills. Mindfulness, 2(3), 194-200. http://dx.doi.org/10.1007/s12671-011-0060-7

Veenhoven, R. (2007). Healthy happiness: effects of happiness on physical health and the consequences for $\begin{array}{llll}\text { preventative health care. Journal of Happiness Studies, 9, 449-469. } & \text {. }\end{array}$ http://dx.doi.org/10.1007/s10902-006-9042-1

Veenhoven, R. (2011). Measures of Happiness. World Database of Happiness, Erasmus University. Retrieved from http://worlddatabaseofhappiness.eur.nl/

Voigt, C., Brown, G., \& Howat, G. (2011). Health and medical tourism. Wellness tourists in search of transformation. Tourism Review, 66(1/2), 16-30. http://dx.doi.org/10.1108/16605371111127206

Wallace, B. A. (2005). Genuine happiness: Meditation as the path to fulfillment. New York, NY: Wiley

Wearing, S., \& Neil, J. (2009). Ecotourism - impacts, potentials and possibilities (2nd ed.). Oxford, UK: Butterworth-Heinemann.

Weijer-Bergsma, E., Formsma, A. R., Bruin, E. I., \& Bögels, S. M. (2012). The effectiveness of mindfulness training on behavioral problems and attentional functioning in adolescents with ADHD. Journal of Child and Family Studies, 5, 775-787. http://dx.doi.org/10.1007/s10826-011-9531-7

Zeidan, F., Martucci, K. T., Kraft, R. A., Gordon, N. S., McHaffie, J. G., \& Coghill, R. C. (2011). Brain Mechanisms Supporting the Modulation of Pain by Mindfulness Meditation. Journal of Neuroscience, 31(14), http://dx.doi.org/ 10.1523/JNEUROSCI.5791-10.2011

Zsolnai, L. (2011). The Palgrave Handbook of Spirituality and Business. Palgrave Macmillan, London.

\section{Copyrights}

Copyright for this article is retained by the author(s), with first publication rights granted to the journal.

This is an open-access article distributed under the terms and conditions of the Creative Commons Attribution license (http://creativecommons.org/licenses/by/3.0/). 